\title{
Are All Independent Directors the Same? Evidence from Italian Listed Companies
}

\author{
Paolo Tenuta ${ }^{1}$, Domenico Rocco Cambrea ${ }^{1} \&$ Debora Fazzari ${ }^{1}$ \\ ${ }^{1}$ Department of Business Science and Law of University of Calabria, Italy \\ Correspondence: Paolo Tenuta, Department of Business Science and Law of University of Calabria, Italy. E-mail: \\ paolo.tenuta@unical.it
}

Received: March 8, 2018

Accepted: June 24, 2018

Online Published: August 1, 2018

doi:10.5539/ijbm.v13n9p78

URL: https://doi.org/10.5539/ijbm.v13n9p78

\begin{abstract}
The purpose of this study is to investigate the impact of independent directors on the performance of Italian listed firms on the Milan Stock Exchange during the period 2006-2015. After applying a Fixed Effect Model, the empirical findings suggest that the composition of the board may affect corporate performances and, more specifically, a significant relationship emerges between the presence of independent directors within the Board and company results. Specifically, independent directors and independent female directors positively affect firm performance. Diversely, independent busy directors, those with hold more than three directorship in other boards, do not affect performance.
\end{abstract}

Keywords: independent directors, corporate governance, performance

\section{Introduction}

The purpose of many studies on corporate governance is to seek a relationship between board characteristics and company performance. A large part of the economic literature, in fact, analyzes the main determinants of governance mechanisms in order to verify their effect on business performance (Core, Guay, \& Rusticus, 2006; La Porta, Lopez-de-SIlanes, Shleifer, \& Vishny, 1998). In particular, in recent years many university researchers have moved their research interests on characteristics of the board of directors (Daily, Dalton, \& Cannella, 2003; Di Pietra, Grambovas, Raonic, \& Riccaboni, 2008). Despite this, the empirical evidence on the relationship between the composition of the board and financial performance is still uncertain (Dalton, Daily, Ellstrand, \& Johnson, 1998; Dalton, Daily, Johnson, \& Ellstrand, 1999; Minichilli, Zattoni, \& Zona, 2009). An important theme is represented by the investigation of the personal characteristics that members of the board should have to improve the control of the management's work and to provide a valid support to the decision-making process of the company (Hermalin \& Weisbach, 2001; Stiles \& Taylor 2001; Zattoni, 2006).

The attention given by scholars to the composition of the Board of directors is justified by the fact that top management is appointed in the same place. The main shareholders often heavily manage the board of directors of listed Italian companies. Therefore, there is little space for minority shareholders. The presence of a board of directors, designed with regard to the international best practices, should be able to mitigate agency problems (Jensen, 1993) and encourage managers to work properly to ensure the satisfaction of stakeholders' interests. The board of directors should be capable to prevent opportunistic behavior both of the controlling shareholder and of the managers: in this way, agency costs deriving from opportunistic managerial interventions can be limited. The category of independent directors is considered most appropriate to supervise managerial operations and the pursuit of social interest by the same subject, to prevent opportunistic behavior or influenced by extra-social interest of the executive directors. Many authors have identified independent directors as a valuable tool to achieve this aim. Other studies, however, have criticized the useful of this figure, considering it impossible to import this type of administrator into our system because of it having been developed in an American and British context, one very different from Italian markets.

The debate on the part of independent members in the boards, as controllers of management which tendentially pursues personal interests, is already present in Fama \& Jensen (1983), according to which the optimal structure of the board of directors requires executive directors, supported by non-executive directors who should intervene when it is necessary to make strategic decisions and to resolve potential conflicts of interest between managers and shareholders. This kind of directors, having no particular links with the company, is less likely to be 
involved in collusive agreements with the management. Lorsch \& MacIver (1989) also state that independent directors, owing to their position, are able to value and monitor the company's activities. Byrd and Hickman, (1992) note that independent directors are responsible for protecting and promoting the interests of minority shareholders (Fernandes, 2008). Finally, Milstein (1993) defines "constructive tension" the connections between shareholders and directors and between members of the board and managers in case in which the independence of a part of the Board of directors is credible. According to Bhagat and Black (2001), the independent directors represent institutions useful to support shareholders in identifying problems of transparency and disclosure of information.

The goal of our study is to test the existence of a relationship between the percentages of independent directors in the boards and the performance of Italian listed companies, considering both the personal characteristics and professional experiences of the independent members, as gender and other directorships held in companies.

The paper is divided into three main sections. The second paragraph describes the literature about the independent directors and company performance, and illustrates the research hypotheses. Successively, we present the sample and the econometric model applied for the empirical analysis. Lastly, we discuss the results of the empirical analysis and the main conclusions.

\section{Research Hypotheses}

The literature aimed to study the effects of the presence of independent directors on the performance of companies is increasing following the recent international financial crisis. The number of independent directors is growing in listed companies throughout the world. For this reason, the literature has been enriched with empirical contributions aimed to measure the effects of their presence on the performances of the boards and on those of the company. According to several studies, the presence of independent directors has positive effects on the ability to attract foreign investors. In addition, the studies that investigate the link between the presence of independent directors and performance indicate, in most cases, positive effects on performance when the percentage of non-executive directors rises.

The hypotheses that we intend to investigate with the present contribution, based on an institutional context such as the Italian one, are illustrated below:

\subsection{Independent Directors and Firm Performance}

Following the Agency theorists, the board of directors must perform its functions in order to ensure an efficient management of the company and improve the business results. Furthermore, it must protect shareholders from any operations carried out by managers in their own interests. Dittmar and Mahrt-Smith (2007) verify that companies characterized by weak corporate governance use internal resources in an inefficient way, causing a decline in firm value. Whether the use of resources by the manager is poorly controlled the same resources are exposed to the pursuit of useless investments (Jensen \& Meckling, 1976) or simply to derive personal advantages despite the global enterprise value. An increase in the independence of the board of directors can give a stronger corporate governance, capable of adequately protecting the interests of all shareholders and, at the same time, providing excellent monitoring of managerial operations. The independent directors are more likely to protect the interests of shareholders than the other directors (Volonté, 2015) and to remove the non-performing CEOs (Weisbach, 1988). Much empirical evidence underlines the safeguard role that independent directors face in the presence of agency problems. A greater number of independent members, who are undoubtedly in a better position to monitor managers (Dunn, 1987), is needed to observe their work carefully and thus gain a better understanding of company strategies (Rubino, Tenuta, \& Cambrea, 2016). Moreover, they are particularly interested in safeguarding their professional reputation as "over the top" advisors (Fama \& Jensen, 1983). Therefore, they perform their duties with complete transparency and diligence. In addition, boards of directors that involve numerous independent members may reduce the managerial domain and information asymmetry (Rubino, Tenuta, \& Cambrea, 2016) and improve the board's effectiveness in advising company operations (Chahine \& Filatotchev, 2008). Gani \& Jermias (2006) have highlighted that board independence has a greater effect for companies that pursue a cost-efficiency strategy because they benefit more from the independence and monitoring of the board. In companies that pursue an innovation strategy, instead, the control of independents could limit the initiatives of managers to undertake innovative actions and new investments. Based on these considerations, it is assumed that an increase in independent directors will lead to better business performance.

H.1: Independent directors positively affect company performance. 


\subsection{Independent Busy Directors and Firm Performance}

The question of administrators who sit on different board of directors can be analyzed from two points of view (Tenuta \& Cambrea, 2016). On the one hand, the reputation effect (Jiraporn et al., 2009), provides business benefits and recognizes the status of excellent administrators to members who cover the board of directors simultaneously in multiple boards. Thanks to their experience, they would be able to monitor management effectively and improve the internal process of the board of directors. On the other hand, "busy" directors might tend to dedicate less time to each company, implicating their responsibilities and reducing the activities on managerial monitoring (Ferris, Jagannathan, \& Pritchard, 2003), creating, in this way, serious problems of agency and an involution of company consultancy (Lipton \& Lorsch, 1992). The empirical evidence (Pfeffer \& Salancik, 1978; Zahra \& Pearce; 1989) shows that the busy directors are favored by external markets. They can take advantage of their own professional knowledge and provide several benefits to the firm in which they sit on the boards. Masulis \& Mobbs (2011) also show that busy directors, thanks to their experience and skills, are able to improve the company's performance. In addition, they are valid alternatives for the rotation of the CEO of the companies in which they hold a position. For these reasons, the CEO is encouraged to improve company performance, minimizing possible opportunistic behavior. Some scholars, however, are more dubious about the consideration that "busy" directors can satisfy the interests of shareholders and create added value to the company. Core, Holthausen, \& Larcker (1999) argue that these administrators can be too busy and consequently unable to monitor enterprise management effectively at the same time in many businesses. In the same way, Jiraporn et al. (2009) highlight that "busy" directors attend less frequently board meetings, increasing the unfavourable possibility to not participate in determining important decisions about the company strategies. Shivdasani \& Yermack (1999), argue that busy administrators can determine an increase in agency costs, which destroy business value, because of a low monitoring of managers' actions. Fich \& Shivdasani (2006), confirm that the increase in the number of busy directors leads to a drop in the intensity of control over management. From the analysis of the literature are derived two conflicting results, which do not allow the explicit prediction of the relationship between busy governance and company performance. Despite this, it is hypothesized that their presence on the Board of directors is certainly able to influence the company's performance in one of the hypothetical directions.

H.2: Independent busy directors, those who sit on three or more other corporate boards taken from minority lists influence company performance.

\subsection{Independent Female Directors and Firm Performance}

The recent law that aims to increment the percentage of female directors of listed companies have made the issue concerning gender diversity on the board of directors the subject of considerable interest by scholars from all over the world. Consequently, for some years, lot of researchers have begun to explore the role of female directors on the board through their exclusive capabilities and their ability to affect corporate performance. However, the empirical evidence shows mixed results regarding the relationship between female directors and performance.

Female representation in the organs of the company not only enlarges the filed of potential directors from which administrators can be designated, but also provides the opportunity to differentiate the directors' profiles within the board, adding new point of view that can not be enjoyed on male boards of directors (Hillman et al., 2007). Huse \& Solberg (2006) suggest that gender diversity improves the organizational value and the performance of companies, thanks to skills and points of view different from those of men.

The importance of gender diversity on the board can also be explained according to the agency theory. Numerous studies (Adams \& Funk, 2012; Rhode \& Packel, 2014; Carter et al., 2003) see a better ability to monitor the behavior of managers in order to act in the interest of shareholders in a heterogeneous Board. A diverse board, composed of subjects with various cultural knowledges is the bearer of many different points of view, which will contribute, among other things, to making management more vigilant. Taking into consideration these assumptions, the presence of women on the board should increase the profits of a company, reduce the agency problems and improve the ability to control (Rubino, Tenuta, \& Cambrea, 2016). Terjesen, Couto, and Francisco (2015) show that an independent board has a positive effect on corporate performance when in the board there are female directors. Diversely, when there are no women or there are few, the main effect is negative. This suggests that the presence of independent directors is dangerous to company performance. The study by Liu, Wei, \& Xei (2014) shows that independent directors do not have such a positive and significant impact on the performance of companies, indeed a more positive effect is given by women with executive positions. 
By the analysis of the purchase offers of 1500 companies belonging to the S\&P index, Levi, Li and Zhang (2014) show that women directors helps to enhance shareholder value, because they are less likely to waste internal financial resources. Therefore, female members can save cash resources that could be used in profitable investment projects (Rubino, Tenuta, \& Cambrea, 2016). Nevertheless, it is empirical evidence that shows how excessive monitoring of management can decreasing firm value (Almazan \& Suarez, 2003). Adams \& Ferreira (2007) underline how greater interference by directors in the decision-making process could lead to difficulties in communicating among the directors. In this case, gender diversity may influence firm performance negatively. Ahern \& Dittmar (2012) find, on a sample of Norwegian companies, a negative link between a quota of women and firm value, due to the presence of female directors with no experience as members of the boards. Even Adams \& Ferreira (2009), despite having verified empirically that the gender diversity of the board is positively correlated with the effectiveness of its operations, in a sample of US companies, find a negative relationship between the diversity of the board and the business performance. The authors ascribing the result to the excessive supervision of the female directors. Despite this, most of empirical researches find a positive effect of female on performance, thus we expect that the presence of independent female directors can affect the company's performance positively.

H.3: Independent female directors positively affect company performance.

\section{Sample and Methodology}

The hypotheses are tested on a sample of Italian listed industrial firms from the Stock Exchange in Milan, including in Datastream for the period 2006-2015 (10 years). Corporate board data were hand-collected from the official annual reports on corporate governance firms. All financial variables data come from Datastream, one of the most updated sources for financial information on listed companies. From the initial sample of companies, we excluded companies belonging to the financial sector. Thus, for the empirical analysis, we used a balanced panel of 2045 observations and 210 companies, for which we have a complete set of financial and governance data.

To test the effect of Independent directors on firm performance, the following empirical model is applied:

$$
\begin{gathered}
\text { Adj ROA }=\beta_{0}+\beta_{1} \text { independent directors }+\beta_{2} \text { cash holdings }+\beta_{3} \text { size }+\beta_{4} \text { leverage }+\beta 5 \text { cash flow }++\beta_{6} \text { growth } \\
\text { opportunity }+\beta_{7} \text { CEO duality }+\beta 8 \text { Net Working Capital }+\alpha_{i}+\mu_{t}+\varepsilon_{i, t}
\end{gathered}
$$

As a proxy for firm performance in the study we used ROA, measured as operating income divided by total assets. Considering that the operating performance can be affected by sector, we use a correct index by sector, industry adjusted ROA. Specifically, it is defined as a firm's ROA less the average ROA for firms in the same industry according to the Italian Stock Exchange's industry classification.

To test the hypotheses previously described, our study employs four specific variables of corporate governance. Independent directors are identified by the ratio of independent directors and the number of directors on the board. Independent busy directors are the percentage of independent directors nominated by the minority shareholders who hold more than three directorships. It is a proxy to capture the experience of each member of the board and it is identified by the ratio between the number of independent directors elected by the minority list and with more than three roles in other companies and board size. Independent female directors are the percentage of women independent directors on the board. Information about the structure of the boards of directors were hand-collected by referring to the annual reports on Italian corporate governance reports.

In order to control the firm-specific effects, in the model there are some control variables such as cash holdings, size, leverage, cash flow, tangibility and Duality CEO. To identify the variables to be used in the empirical analysis, we refer to previous studies (Anderson \& Reeb, 2003; Villalonga \& Amit, 2006; Andres, 2008), which consider them as important determinants of firm performance. Cash holdings variable, representative of cash reserves, is given by the ratio of cash and cash equivalents to total assets (Ozkan A. \& Ozkan N., 2004). Size, measured as the natural logarithm of total assets, shows how a superior firm size, offering greater capital guarantees and stability of cash flows, should be inversely proportional to the probability of default. Leverage, calculated as total debt to total assets, helps monitor the ability to acquire additional external financial resources. Cash flows is measured by the ratio between the sum of the pre-tax result plus depreciation and amortization, and total assets. Growth opportunity is measured by the ratio of book value of total assets less the book value of equity plus the market value of equity divided by book value of total assets. CEO duality is a dummy variable that takes value equal to one if the CEO is also the chairman of the board and zero otherwise. Net Working Capital is a measure of liquidity and solvency and is defined as inventories plus receivables minus payables, less cash and cash equivalents, divided by total assets. 


\section{Analyses and Results}

\subsection{Descriptive Statistics and Correlations}

Table 3 presents the main descriptive statistics for the sample. Referring to the presence of independent directors on the board and their characteristics, the results show that the independent directors are, on average, $39 \%$ of the members of the board. Only $2 \%$ of the members of the board are the interlocked independent directors elected by minority shareholders. Finally, women independent directors represent $5 \%$ of the board's members. With reference to the other characteristics of the board, the results indicate that, on average, the CEO is also the Chairman of the Board of directors in $27 \%$ of the cases.

Table 1. Descriptive statistics

\begin{tabular}{llllll}
\hline Variables & Mean & $\begin{array}{l}\text { Standard } \\
\text { Deviation }\end{array}$ & $\begin{array}{l}\text { 25th } \\
\text { Percentile }\end{array}$ & Median & 75th Percentile \\
\hline Adjusted ROA & -0.00 & 0.11 & -0.03 & 0.01 & 0.04 \\
Independent directors & 0.39 & 0.18 & 0.29 & 0.38 & 0.50 \\
Independent busy directors & 0.02 & 0.09 & 0.00 & 0.00 & 0.00 \\
Independent female directors & 0.05 & 0.06 & 0.00 & 0.00 & 0.09 \\
Cash holdings & 0.11 & 0.12 & 0.04 & 0.08 & 0.14 \\
Size & 13.07 & 1.89 & 11.75 & 12.78 & 14.22 \\
Leverage & 0.31 & 0.20 & 0.17 & 0.30 & 0.42 \\
Cash Flow & 0.04 & 0.09 & 0.02 & 0.05 & 0.08 \\
Growth opportunity & 1.51 & 0.81 & 1.09 & 1.30 & 1.66 \\
CEO Duality & 0.27 & 0.44 & 0.00 & 0.00 & 1.00 \\
Net Working Capital & -0.05 & 0.23 & -0.12 & -0.03 & 0.08 \\
\hline
\end{tabular}

Table 2. Correlation matrix

\begin{tabular}{|c|c|c|c|c|c|c|c|c|c|c|c|c|}
\hline & Variables & 1 & 2 & 3 & 4 & 5 & 6 & 7 & 8 & 9 & 10 & 11 \\
\hline 1 & Adjusted ROA & 1.000 & & & & & & & & & & \\
\hline 2 & Independent directors & 0.028 & 1.000 & & & & & & & & & \\
\hline \multirow[t]{2}{*}{3} & Independent busy directors & 0.010 & 0.189 & 1.000 & & & & & & & & \\
\hline & & $(0.707)$ & $(0.000)$ & & & & & & & & & \\
\hline 4 & & $(0.528)$ & $(0.000)$ & $(0.992)$ & & & & & & & & \\
\hline \multirow[t]{2}{*}{5} & Cash holdings & 0.058 & -0.090 & -0.108 & 0.009 & 1.000 & & & & & & \\
\hline & & $(0.012)$ & $(0.000)$ & $(0.000)$ & $(0.704)$ & & & & & & & \\
\hline \multirow[t]{2}{*}{6} & Size & 0.160 & 0.331 & 0.198 & 0.071 & -0.081 & 1.000 & & & & & \\
\hline & & $(0.000)$ & $(0.000)$ & $(0.000)$ & $(0.003)$ & $(0.000)$ & & & & & & \\
\hline 8 & & $(0.000)$ & $(0.972)$ & $(0.503)$ & $(0.028)$ & $(0.000)$ & $(0.000)$ & $(0.000)$ & & & & \\
\hline \multirow[t]{2}{*}{9} & Growth opportunity & 0.227 & -0.039 & -0.019 & 0.037 & 0.251 & -0.132 & -0.325 & 0.285 & 1.000 & & \\
\hline & & $(0.000)$ & $(0.094)$ & $(0.497)$ & $(0.117)$ & $(0.000)$ & $(0.000)$ & $(0.000)$ & $(0.000)$ & & & \\
\hline \multirow[t]{2}{*}{10} & CEO Duality & -0.038 & -0.179 & -0.043 & -0.075 & 0.064 & -0.175 & -0.056 & -0.058 & 0.057 & 1.000 & \\
\hline & & $(0.102)$ & $(0.000)$ & $(0.109)$ & $(0.001)$ & $(0.006)$ & $(0.000)$ & $(0.015)$ & $(0.012)$ & $(0.014)$ & & \\
\hline \multirow[t]{2}{*}{11} & Net Working Capital & 0.322 & -0.104 & -0.009 & -0.077 & -0.041 & 0.009 & -0.527 & 0.392 & 0.245 & -0.049 & 1.000 \\
\hline & & $(0.000)$ & $(0.000)$ & $(0.737)$ & $(0.001)$ & $(0.081)$ & $(0.691)$ & $(0.000)$ & $(0.000)$ & $(0.000)$ & $(0.038)$ & \\
\hline
\end{tabular}

Observing the correlation between ROA and corporate governance variables, we note that there is no significant correlation between the independent directors' variables and performance. On the other hand, we note a positive and significant correlation with the financial characteristics of the company. In particular, cash holdings, cash flow and size are positively correlated to our dependent variable. On the contrary, consistent with the previous literature, the ROA is negatively and significantly correlated with the debt. 
The following table show the results of the empirical analysis that investigates the relationship between independent directors and firm performance. Because employing OLS regressions can determine inaccurate results and to mitigate heterogeneity problems, a fixed effect panel model is applied. The decision to make this econometric technique comes from by other studies that examine the link between governance and company performance (Adams \& Ferreira, 2009; Ahern \& Dittmar; 2012).

Table 3. Independent directors and firm performance

\begin{tabular}{llll}
\hline VARIABLES & $(1)$ & $(2)$ & $(3)$ \\
\hline Independent directors & $0.0414^{* * *}$ & & \\
& $(0.0037)$ & & \\
Independent busy directors & & -0.0014 & \\
& & $(0.9805)$ & $0.0538^{*}$ \\
Indipendent female directors & & & $(0.0758)$ \\
& & & $0.0807^{* * *}$ \\
Cash holdings & $0.1120^{* * *}$ & $0.1542^{* * *}$ & $(0.0014)$ \\
Size & $(0.0000)$ & $(0.0000)$ & -0.0046 \\
& 0.0026 & $-0.0245^{* * *}$ & $(0.4255)$ \\
Leverage & $(0.5604)$ & $(0.0019)$ & $-0.1344^{* * *}$ \\
Cash flow & $-0.1119^{* * *}$ & $-0.1539^{* * *}$ & $(0.0000)$ \\
Growth opportunity & $(0.0000)$ & $(0.0000)$ & $0.6037^{* * *}$ \\
& $0.5433^{* * *}$ & $0.5672^{* * *}$ & $(0.0000)$ \\
Ceo Duality & $(0.0000)$ & $(0.0000)$ & $0.0094^{* *}$ \\
Net Working Capital & $0.0088^{* *}$ & 0.0089 & $(0.0390)$ \\
Constant & $(0.0237)$ & $(0.1407)$ & -0.0072 \\
& -0.0057 & -0.0030 & $(0.2973)$ \\
Year Dummies & $(0.3211)$ & $(0.7473)$ & $0.0607^{* * *}$ \\
Observations & $0.0629^{* * *}$ & $0.1182^{* * *}$ & $(0.0005)$ \\
R-squared & $(0.0000)$ & $(0.0000)$ & 0.0295 \\
Number of Id & -0.0815 & $0.2893^{* *}$ & $(0.6954)$ \\
\hline pva & $(0.1751)$ & $(0.0307)$ & YES \\
& YES & YES & 1,675 \\
& 2,045 & 1,252 & 0.2987 \\
& 0.2765 & 0.2845 & 192 \\
\hline
\end{tabular}

pval in parentheses $\left(* * * \mathrm{p}<0.01, * * \mathrm{p}<0.05,{ }^{*} \mathrm{p}<0.1\right)$.

The empirical analysis aims to evaluate the relationship between the independent directors and their characteristics, such as their experience and their gender, and firm performance. With reference to the effect of the control variables on firm performance, the variables related to cash holdings, cash flow, growth opportunity and net working capital are positively correlated to company performance. Diversely, we identify a negative relationship between the performance and leverage.

About research hypotheses previously formulated, the empirical results reported in column (1) of table 3 confirm hypothesis H.1. The coefficient of Independent directors' variable is positive and statistically significant $(\beta=$ $0.0414, \mathrm{p}<0.01)$. Thus, a board characterized by a high fraction of independent directors improves the business performance. The positive effect is coherent with the perspective of Chahine and Filatotchev (2008), who argue that boards with a large percentage of independent directors not only monitor the management operations, but also enhance the efficiency and effectiveness of the entire board. The main shareholder wishes to select, as independent directors on the board, subjects with strong professional capabilities and not looking at any personal links. Consequently, having some confidence in independent directors on the board, with whom there is a durable effect, can improve the company and its performance.

On contrary, our second hypothesis, concerning the percentage of the independent busy directors, members who hold more than three directorships in other companies, has not been verified. Therefore, a board with independent directors that held directorships on other boards, so members with lot of experiences and strong skills, are not able to influence firm performance. The results do not recognize both the benefits deriving from the reputational effect 
(Jiraporn et al., 2009) and the disadvantages deriving from the agency perspective (Carpenter \& Westphal, 2001).

Finally, the last hypothesis regarding the implications of the presence of female independent directors on the company is verified because the variable Independent female directors is positive and statistically significant ( $\beta=$ $0.0538, \mathrm{p}<0.10$ ). The results confirm the numerous studies that have highlighted the presence of considerable benefits for companies that have female governance in their boards. Our findings agree with the considerations made by the agency theory, which claims that the presence of women on the board should increase the profits of a company, since they would reduce the agency issues within the companies and improve the ability to control the managers. Over the last few years, the process of expansive policies of gender quotas has begun in Italian listed companies. Therefore, their current presence on company boards is still very limited. According to the Critical Mass Theory (Erkut, Kramer, \& Konrad, 2008), the contribution of women on the boards can make a difference and therefore be bearers of real innovations in business, but their number must be at least three women (Torchia, Calabro, Huse, \& Brogi, 2010).

\section{Conclusions}

This paper analyzed the role and figure of independent directors within the corporate governance of Italian listed firms, taking into account the legislative process that led to the current definition of the corporate governance model, showing its peculiarities and analyzing the changes brought about by recent regulatory changes. The objective of the analysis was to verify the existence of a relationship between the presences of independent directors on the BoDs, also considering the positions held in the company, and the corporate performance of the Italian listed companies observed over the period 2006-2015. Considering a sample of 2045 observations and 210 companies, we focused on the characteristics of the independent directors, which can affect, both positively and negatively, the quality of board monitoring.

The empirical results show that board of directors affects business performance. These results display a significant relationship between the presence of independent directors within the Board of directors and company performance. Specifically, companies with large percentage of independent members determine a better performance. The result obtained seems to confirm what was previously achieved by other studies. In fact, also Chahine \& Filatotchev (2008) reveal a positive impact of independent directors on business performance, increasing the quality of monitoring on any management opportunistic behavior and improving the board's effectiveness in advising business operations. To reinforce this concept, also Masulis \& Mobbs (2011), thanks to a study on a sample of US firms belonging to the S\&P 1500, state that the firms in which there are independent directors present better performances in terms of ratios balance sheet.

According to the empirical literature (Masulis \& Mobbs, 2011; Pfeffer \& Salancik, 1978; Zahra \& Pearce, 1989) busy directors are good administrators for the companies. Consequently, academic researchers argue that busy directors are preferred thanks to their skills that allow them to better supervise management. In addition, they are able to improve board decision-making ability. They can help the firm to have better access to external credit markets. All these reasons lead to improving the financial performance. In the same way, however, as the results of this work show, the figure of "independent busy directors", especially those taken from the minority list, do not have an effect on the company and therefore do not significantly affect business performance. This must be analyzed and assessed according to the type of directors. It can be said that the independents drawn from the minority list are not so inclined to an efficient monitoring on management.

With reference to the last hypothesis, when we analyze female governance, we note that when they hold the role of independent directors, they influence company business performance positively. All this confirms what has already been affirmed by numerous studies, that women are much more precise and effective when they perform a monitoring function on the management's work. Moreover, they are not influential and protect the interests of shareholders avoiding the possible conflicts that can be created with managers. They appear to be even more severe monitors (Adams \& Ferreira, 2009).

The research result allows some interesting implications for the management of the companies to be drawn consistent with the CONSOB vision and the self-regulatory code, reinforcing the vision of the agency theory. Therefore, when future board members are elected, it is desirable to comply not only with the suggestions made by the supervisory, but also with the results deriving from detailed empirical studies. The evidence emerged from the study must be interpreted taking into consideration the limit deriving from the use of a sample of only Italian companies. Indeed, although this work contributes with the practical implications to expand the current literature on independent directors, there are also few limitations that must be acknowledged. For instance, the study relies on a single country, which is relatively small sample in terms of a number of listed companies, whereas a more extensive study, preferably a cross-country analysis, could provide a richer dataset of observations. Moreover, 
when investigating the relationship between independent directors and corporate performance, some moderating forces such as institutional context or team proximity might be taken into account. Finally, our research is limited to listed firms, while future studies may extend the investigation also to private firms. Therefore, the results do not allow a direct comparison with those of other studies that instead are based on contexts different from the Italian one or to perform analyzes on several countries.

\section{References}

Adams, R. B., \& Ferreira, D. (2007). A theory of friendly boards. Journal of Finance, 62(1), 217-250. https://doi.org/10.1111/j.1540-6261.2007.01206.x

Adams, R. B., \& Ferreira, D. (2009). Women in the boardroom and their impact on governance and performance. Journal of Financial Economics, 94(2), 291-309. https://doi.org/10.1016/j.jfineco.2008.10.007

Adams, R. B., \& Funk, P. (2012). Beyond the Glass Ceiling: Does Gender Matter? Management Science, 58(2), 219-235. https://doi.org/10.1287/mnsc. 1110.1452

Ahern, K. R., \& Dittmar, A. K. (2012). The changing of the boards: The impact on firm valuation of mandated female board representation. Quarterly Journal of Economics, 127(1), 137-197. https://doi.org/10.1093/qje/qjr049

Almazan, A., \& Suarez, J. (2003). Entrenchment and Severance Pay in Optimal Governance Structures. Journal of Finance, 58(2), 519-547. https://doi.org/10.1111/1540-6261.00536

Anderson, R. C., \& Reeb, D. M. (2003). Founding-Family Ownership and Firm Performance: Evidence from the S\&P 500. The Journal of Finance, 58(3), 1301-1328. https://doi.org/10.1111/1540-6261.00567

Andres, C. (2008). Large shareholders and firm performance - An empirical examination of founding-family ownership. Journal of Corporate Finance, 15(14), 431-445. https://doi.org/10.1016/j.jcorp

Baysinger, B. D., Kosnik, R. D., \& Turk, T. A. (1991). Effects of Board and Ownership Structure on Corporate R\&D Strategy. The Academy of Management Journal, 34(1), 205-214. https://doi.org/10.2307/256308

Bhagat, S., \& Black, B. (2001). The Non-Correlation Between Board Independence and Long Term Firm Performance The Non-Correlation Between Board Independence and Long-Term Firm Performance. Journal of Corporation Law, 27(2), 231-273. https://doi.org/10.2139/ssrn.133808

Byrd, J. W., \& Hickman, K. A. (1992). Do outside directors monitor managers?. Evidence from tender offer bids. Journal of Financial Economics, 32(2), 195-221. https://doi.org/10.1016/0304-405X(92)90018-S

Carpenter, M. A., \& Westphal, J. D. (2001). The strategic context of external network ties: Examining the impact of director appointments on board involvement in strategic decision making. Academy of Management Journal. https://doi.org/10.2307/3069408

Carter, D. A., Simkins, B. J., \& Simpson, G. W. (2003). Corporate Governance, Board Diversity, and Firm Value. The Financial Review, 38(1), 33-53. https://doi.org/10.1111/1540-6288.00034

Chahine, S., \& Filatotchev, I. (2008). The effects of information disclosure and board independence on IPO discount. Journal of Small Business Management, 46(2), 219-241. https://doi.org/10.1111/j.1540-627X.2008.00241.x

Core, J. E., Guay, W. R., \& Rusticus, T. O. (2006). Does weak governance cause weak stock returns? An examination of firm operating performance and investors' expectations. Journal of Finance, 61(2), 655-687. https://doi.org/10.1111/j.1540-6261.2006.00851.x

Core, J. E., Holthausen, R. W., \& Larcker, D. F. (1999). Corporate governance, chief executive officer compensation, and firm performance. Journal of Financial Economics, 51(3), 371-406. https://doi.org/10.1016/S0304-405X(98)00058-0

Daily, C. M., Dalton, D. R., \& Cannella, A. A. (2003). Corporate governance: Decades of dialogue and data. Academy of Management Review. https://doi.org/10.5465/AMR.2003.10196703

Dalton, D. R., Daily, C. M., Ellstrand, A. E., \& Johnson, J. L. (1998). Meta-analytic reviews of board composition, leadership structure, and financial performance. Strategic Management Journal, 19(3), 269-290. https://doi.org/10.1002/(SICI)1097-0266(199803)19:3<269::AID-SMJ950>3.0.CO;2-K

Dalton, D. R., Daily, C. M., Johnson, J. L., \& Ellstrand, A. E. (1999). Number of Directors and Financial Performance: A Meta-Analysis. Academy of Management Journal, 42(6), 674-686.

Di Pietra, R., Grambovas, C. a., Raonic, I., \& Riccaboni, A. (2008). The effects of board size and "busy" 
directors on the market value of Italian companies. Journal of Management \& Governance, (May 2016), 1-19. https://doi.org/10.1007/s10997-008-9044-y

Dittmar, A., \& Mahrt-Smith, J. (2007). Corporate governance and the value of cash holdings. Journal of Financial Economics, 83(3), 599-634. https://doi.org/10.1016/j.jfineco.2005.12.006

Dunn, R. (1987). Research on instructional environments: Implications for student achievement and attitudes. Professional School Psychology, 2(1), 43-52. https://doi.org/10.1037/h0090528

Erkut, S., Kramer, V. W., \& Konrad, A. M. (2008). 18. Critical mass: does the number of women on a corporate board make a difference? Women on Corporate Boards of Directors: International Research and Practice, 222.

Evans, J., Evans, R., \& Loh, S. (2002). Corporate governance and declining firm performance. INTERNATIONAL JOURNAL OF BUSINESS STUDIES, 10(1), 1-18.

Fama, E. F., \& Jensen, M. C. (1983). Separation of Ownership and Control Separation of Ownership and Control. Journal of Law and Economics, 26(2), 301-325. https://doi.org/10.1086/467037

Fernandes, N. (2008). EC: Board compensation and firm performance: The role of "independent" board members. Journal of Multinational Financial Management, 18(1), 30-44. https://doi.org/10.1016/j.mulfin.2007.02.003

Ferris, S. P., Jagannathan, M., \& Pritchard, A. C. (2003). Too Busy to Mind the Business? Monitoring by Directors with Multiple Board Appointments. Journal of Finance, 58(3), 1087-1111.

Fich, E. M., \& Shivdasani, A. (2006). Are Busy Boards Effective Monitors? Journal of Finance, 61(2), 689-724. https://doi.org/10.1111/j.1540-6261.2006.00852.x

Gani, L., \& Jermias, J. (2006). Investigating the effect of board independence on performance across different strategies. The International Journal of Accounting, 41(3), 295-314.

Hillman, A. J., Shropshire, C., \& Cannella Jr, A. A. (2007). Organizational predictors of women on corporate boards. Academy of Management Journal, 50(4), 941-952.

Huang, J., \& Kisgen, D. J. (2013). Gender and corporate finance: Are male executives overconfident relative to $\begin{array}{lllll}\text { female executives? Journal of Financial Economics, } & \text { 108(3), }\end{array}$ https://doi.org/10.1016/j.jfineco.2012.12.005

Huse, M., \& Grethe Solberg, A. (2006). Gender-related boardroom dynamics: How Scandinavian women make and can make contributions on corporate boards. Women in Management Review, 21(2), 113-130.

Jensen, M. C. (1993). The Modern Industrial Revolution, Exit, and the Failure of Internal Control Systems. Journal of Finance, 48(3), 831-880. https://doi.org/10.1111/j.1540-6261.1993.tb04022.x

Jensen, M. C., \& Meckling, W. H. (1976). Theory of the firm: Managerial behavior, agency costs and ownership structure. Journal of Financial Economics, 3(4), 305-360. https://doi.org/10.1016/0304-405X(76)90026-X

Jiraporn, P., Davidson, W. N., DaDalt, P., \& Ning, Y. (2009). Too busy to show up? An analysis of directors' absences. Quarterly Review of Economics and Finance, 49(3), 1159-1171. https://doi.org/10.1016/j.qref.2008.08.003

John, K., \& Senbet, L. W. (1998). Corporate governance and board effectiveness. Journal of Banking \& Finance, 22(4), 371-403. https://doi.org/10.1016/S0378-4266(98)00005-3

Kramer, V. W., Konrad, A. M., Erkut, S., \& Hooper, M. J. (2007). Critical Mass on Corporate Boards : Why Three or More Women Enhance Governance. Governance, 1-3. https://doi.org/10.1007/s10551-011-0815-z

La Porta, R., Lopez-de-SIlanes, F., Shleifer, A., \& Vishny, R. W. (1998). Law and Finance. Journal of Political Economy, 106(6), 11131-55. https://doi.org/10.1086/250042

Levi, M., Li, K., \& Zhang, F. (2014). Director gender and mergers and acquisitions. Journal of Corporate Finance, 28, 185-200. https://doi.org/10.1016/j.jcorpfin.2013.11.005

Lippi, A., Di Battista, M. L., Vella, F., Guglielmetti, R., Aliberti Amidani, L., Cervellione, R., ... Gozzi, G. (2015). Il punto sugli amministratori indipendenti. LA VOCE DEGLI INDIPENDENTI, (3), 31-49.

Lipton, M., \& Lorsch, J. W. (1992). A modest proposal for improved corporate governance. The Business Lawyer, 59-77.

Liu, Y., Wei, Z., \& Xie, F. (2014). Do women directors improve firm performance in China? Journal of 
Corporate Finance, 28, 169-184. https://doi.org/10.1016/j.jcorpfin.2013.11.016

Lorsch, J., \& Young, J. (1989). Pawns or potentates: The reality of America's corporate boards. The Executive, 4(4), 85-87.

Mariateresa, T., Calabrò, A., Huse, M., \& Brogi, M. (2010). Critical Mass Theory and Women Directors' Contribution to Board Strategic Tasks. SSRN Electronic Journal, 6(October 2015), 42-51. https://doi.org/10.2139/ssrn.1861447

Masulis, R. W., \& Mobbs, S. (2011). Are All Inside Directors the Same? Evidence from the External Directorship Market. Journal of Finance, 66(3), 823-872. https://doi.org/10.1111/j.1540-6261.2011.01653.x

Milstein, M. M. (1993). Changing the Way We Prepare Educational Leaders: The Danforth Experience. ERIC.

Minichilli, A., Zattoni, A., \& Zona, F. (2009). Making boards effective: An empirical examination of board task $\begin{array}{llll}\text { performance. British Journal of } & \text { Management, }\end{array}$ https://doi.org/10.1111/j.1467-8551.2008.00591.x

Ozkan, A., \& Ozkan, N. (2004). Corporate cash holdings: An empirical investigation of UK companies. Journal of Banking and Finance, 28(9), 2103-2134. https://doi.org/10.1016/j.jbankfin.2003.08.003

Pfeffer, J. (1972). Size and Composition of Corporate Boards of Directors: The Organization and its Environment. Source: Administrative Science Quarterly, 17(2), 218-228. https://doi.org/10.2307/2393956

Rhode, D. L., \& Packel, A. K. (2014). Diversity on corporate boards: how much difference does differecen male? Delaware Journal of Corporate Law, 39, 363-410. https://doi.org/10.1525/sp.2007.54.1.23.

Rubino, F. E., Tenuta, P., \& Cambrea, D. R. (2017). Board characteristics effects on performance in family and non-family business: a multi-theoretical approach. Journal of Management \& Governance, 21(3), 623-658. https://doi.org/10.1007/s10997-016-9363-3

Salancik, G. R., \& Pfeffer, J. (1978). A Social Information Processing Approach to Job Attitudes and Task Design. Administrative Science Quarterly, 23(2), 224. https://doi.org/10.2307/2392563

Shivdasani, A., \& Yermack, D. (1999). CEO involvement in the selection of new board members: An empirical analysis. Journal of Finance, 54(5), 1829-1853. https://doi.org/10.1111/0022-1082.00168

Shleifer, A., \& Vishny, R. W. (1989). Management entrenchment. The case of manager-specific investments. Journal of Financial Economics, 25(1), 123-139. https://doi.org/10.1016/0304-405X(89)90099-8

Shleifer, A., \& Vishny, R. W. (1997). A Survey of gorporate governance. The Journal of Finance, 52(2), 737-783. https://doi.org/10.1111/j.1540-6261.1997.tb04820.x

Smith, A. (1950). An Inquiry into the Nature and Causes of the Wealth of Nations, (1776). Methuen.

Stiles, P., \& Taylor, B. (2001). Boards at work: How directors view their roles and responsibilities: How directors view their roles and responsibilities. OUP Oxford.

Tenuta, P., \& Cambrea, D. R. (2016). Consiglio di amministrazione e valore d'impresa. Impresa Progetto Electronic Journal of Management, (1).

Terjesen, S., Couto, E. B., \& Francisco, P. M. (2016). Does the presence of independent and female directors impact firm performance? A multi-country study of board diversity. Journal of Management and Governance, 20(3), 447-483. https://doi.org/10.1007/s10997-014-9307-8

Villalonga, B., \& Amit, R. (2006). How do family ownership, control and management affect firm value? Journal of Financial Economics, 80(2), 385-417. https://doi.org/10.1016/j.jfineco.2004.12.005

Volonté, C. (2015). Boards: Independent and committed directors? International Review of Law and Economics, 41, 25-37.

Weisbach, M. S. (1988). Outside directors and CEO turnover. Journal of Financial Economics, 20, 431-460.

Yermack, D. (2006). Board members and company value. Financial Markets and Portfolio Management, 20(1), 33-47.

Zahra, S., \& Pearce, J. (1989). Boards of Directors and Corporate Financial Performance: A Review and Integrative Model. Journal of Management, 15(2), 291-334. https://doi.org/10.1177/014920638901500208

Zattoni, A. (2000). Economia e governo dei gruppi aziendali (pp. 1-256). Egea.

Zattoni, A. (2006). Assetti proprietari e corporate governance (pp. 1-414). Egea. 


\section{Copyrights}

Copyright for this article is retained by the author(s), with first publication rights granted to the journal.

This is an open-access article distributed under the terms and conditions of the Creative Commons Attribution license (http://creativecommons.org/licenses/by/4.0/). 